\title{
EDMODO IMPACTS: MEDIATING DIGITAL CLASS AND ASSESSMENT IN ENGLISH LANGUAGE TEACHING
}

\author{
Sumardi Sumardi ${ }^{1 *}$, Muamaroh Muamaroh ${ }^{2}$ \\ ${ }^{1}$ Universitas Sebelas Maret, Indonesia \\ ${ }^{2}$ Universitas Muhammadiyah Surakarta, Indonesia \\ *e-mail: sumardi74@staff.uns.ac.id
}

\begin{abstract}
Information technology-based instruction, such as Edmodo, gains its popularity as it is likely to strengthen the role of teachers, schools, and parents for the sake of optimizing student learning outcomes. This study set out to explore how Edmodo was utilized to mediate digital class in English language teaching (ELT); how Edmodo facilitated students' engagement during the class; and how Edmodo mediated teachers to assess students' learning outcomes. A qualitative approach was employed and 286 students from a secondary school voluntarily participated in this study. Interviews, online mini-polling, and document analysis were deployed as data collection methods, and data were validated by triangulation and analyzed by following the interactive model data analysis. It revealed that Edmodo was an effective mode to mediate digital class in ELT as the students could interact with their teachers, peers, and course contents effectively, both inside and outside the classroom. The students' engagement was also better in comparison to that of the face-to-face classroom. Finally, Edmodo well-mediated teachers to carry out the computer-based test (CBT); it was an accurate mode of assessment as no cheatings were facilitated; the validity, and reliability of the test could be favorably accomplished.
\end{abstract}

\section{Keywords: digital class, Edmodo, ELT classroom, language assessment}

\section{DAMPAK EDMODO: MEMEDIASI KELAS DAN PENILAIAN DIGITAL DALAM PEMBELAJARAN BAHASA INGGRIS}

\begin{abstract}
Abstrak: Pembelajaran berbasis teknologi informasi (misal menggunakan Edmodo) semakin populer karena dipercaya mampu memperkuat peran guru, sekolah, dan orang tua demi mengoptimalkan hasil belajar siswa. Oleh karena itu, penelitian ini bertujuan mengeksplorasi bagaimana Edmodo dimanfaatkan guru untuk memediasi kelas digital dalam pembelajaran bahasa Inggris (ELT); bagaimana Edmodo memfasilitasi keterlibatan siswa selama proses pembelajaran; dan bagaimana Edmodo menjadi media bagi guru untuk menilai hasil belajar siswa. Penelitian ini mengikuti pendekatan kualitatif dan 286 siswa dari sekolah menengah secara sukarela berpartisipasi selama proses penelitian. Data dikumpulkan melalui wawancara, online mini-polling, dan analisis dokumen. Data kemudian divalidasi dengan triangulasi dan dianalisis dengan mengikuti model analisis data interaktif. Hasil penelitian menunjukkan bahwa Edmodo merupakan moda efektif untuk memediasi kelas digital dalam pembelajaran bahasa Inggris karena siswa dapat berinteraksi dengan guru, teman-teman sekelas dan materi pelajaran secara efektif, baik di dalam maupun di luar kelas. Keterlibatan siswa selama pembelajaran digital juga lebih baik dibandingkan dengan pembelajaran tatap muka. Edmodo juga mejadi media yang baik bagi guru untuk melakukan tes berbasis komputer $(C B T)$; hasil penilaian menjadi lebih akurat karena kecurangan sangat kecil terjadi; validitas dan reliabilitas tes dapat dicapai dengan baik pula.
\end{abstract}

\section{Kata Kunci: kelas digital, Edmodo, kelas ELT, penilaian bahasa}

\section{INTRODUCTION}

The presence of technology for English instructions has been very important as it brings about meaningful instructional practices. Furthermore, Lubis (2018) elucidates that teachers considerably have positive perception of the integration of technology in English Language Teaching. Edmodo, as an information technology-based instructional platform, has been widely used by English teachers in many countries, both English as a second language (Mokhtar, 2016; Mokhtar \& Dzakiria, 2015) and 
English as a foreign language (Ali, 2015; Al-Said, 2015; Ekmekci, 2016; Purnawarman, Susilawati, \& Sundayana, 2016). They report that most students have a positive perception of Edmodo as a medium of English language teaching (ELT) as well and students' engagement during the class gets much better. Students' positive perception does play a pivotal role to promote students' learning strategies (Kosar, 2016; Liu \& Yu, 2012); and also promotes students' learning experience (Al-Zumor, Al-Refaai, Eddin, \& AlRahman, 2013). Additionally, it exhibits that Edmodo has good potential to create a better process of language instruction. Edmodo as one of digital learning media need to be integrated in instructional practices. Zuhdi \& Nurhadi (2019) note further that digital media has potential to optimize the better learning environment. Therefore, the use of Edmodo has recently become an urgent necessity if teachers think about efficiency and effectiveness to establish predetermined instructional goals. Apart from being a mode of instruction, Edmodo can also be utilized by teachers as a mode of assessment. This is a consequence of modern instructions as an internet network is now ubiquitous.

In reference to Edmodo, teachers and students can share notes, links, and documents. It is a mode for both teaching and learning (Mokhtar, 2016) and foreign language instruction and assessment mode (Ekmekci, 2016; Kwok \& Kong, 2016; Qomariyah, Gunarhadi, \& Rejekiningsih, 2019). Edmodo is currently becoming a pivotal instructional technology and more teachers take advantage of Edmodo to design better instructions. In the last decade, Edmodo gains its popularity to use as a medium of instructions. Teachers' awareness to utilize technology-based media is getting higher to improve students' engagement and participation during the instructional practices.

It is different from that of a conventional classroom which focuses more on face-to-face methods and the teaching-learning practices are frequently dominated by teachers, while students just sit in rows of chairs in the classrooms (Kuzu, 2008; Garrett \& Danziger, 2008; Relan \& Gillani, 1997); and teacher-student interactions take place only in front of the classrooms (Li, 2016). Faceto-face instructional practices are likely to be difficult to bring them into the dynamic learning activities as the interactions are restricted to take place solely inside the classrooms. Besides, the conventional instructions, such as the "talk and chalk" technique and classroom lectures, allow the highly restricted amount of information to flow from teachers to students and depend upon the amount of knowledge acquired by teachers (Bakar, 2016) with the results that students may take in inadequate language skills as well.

In the internet era, teachers need to shift partly and/or entirely their conventional instructions to technology-based instructions which are commonly known as a digital class. A digital class refers to a class consisting of at least three enduring practices, such as interactivity, symbolic flexibility, and vast sources of information (Daiute, 2013) and it is facilitated by technology that provides students and teachers some elements of control over time, place, path and/or pace (Rauschenberg, 2016). Integration of technology in instructional practices is a concept of digital class and it is advocated for a wide array of reasons, i.e. engagement, improvement in academic ability, paradigm shift, assessment shift and collaborative learning enhancement (Riasati, Allahyar, \& Tan, 2012); and improves the quality of instructions (Çelik, \& Aytın, 2014; Arkorful \& Abaidoo, 2014; Ghavifekr \& Rosdy, 2015). To sum up, a digital class is an instructional practice facilitated by internetbased technology so that teachers and students may engage and interact with each other easily. For this purpose, Edmodo can be one of the learning platforms to mediate the digital class.

Edmodo has numerous features, such as notes, assignments, poll, backpack, library, and snapshot that facilitate students and teachers to share ideas online. In addition, Edmodo has a feature of 'quiz' that teachers can use as a mode of assessment. The order of test items (set of questions) is automatically randomized by the Edmodo system so that each student has a different order of test items. It is likely to reduce the possibility for students to cheat while taking the tests. Edmodo as an instructional mode for constructing and sharing the collaborativebased knowledge is believed to streamline the instructional practices; to allow teacherstudent intensive communication, and to make the instructional practices to be 'different' (Cakrawati, 2017; Mokhtar \& Dzakiria, 2015). One of the advantages of Edmodo compared with the other social networking sites (SNS) 
is that Edmodo has several features as modes of assessment, such as Quiz, Assignment, and Poll. These features are rewarding a lot for teachers to administer a systematic and accurate assessment. In addition, Edmodo allows teachers to assess students' language skills using different test formats, i.e. multiple-choice, essay, quiz, writing, reading comprehension test, student worksheets, etc. Therefore, Edmodo mediates digital classes in language teaching and serves as an assessment mode.

Some previous researches on the use of Edmodo had been carried out in a wide range of subject areas. Most of the researches were to complement of and/or to cope with the shortcomings of conventional, face-to-face instructional practices. Ma'azi \& Janfeshan (2018) report that students, in general, have positive attitudes towards the application of Edmodo; and students' perceptions of Edmodo are also positive (Al-said, 2015; Cakarawati, 2017; Santikarn \& Wichcadee, 2018; Pardede, 2019). Also, Edmodo allows students to be autonomous learners (Santikarn \& Wichcadee, 2018); allows them to engage in self-directed learning and peer-teaching practices (Thibaut, 2015; Khodary, 2017); facilitates students' engagement during the class (Purnawawarman et al., 2018; Zakana \& Fomsi, 2019); and also mediates and maintains students' motivation to learn (Tsiakyroudi, 2018). Another research authenticates that the use of Edmodo enriches learning experience (Polat, Cagiltay, \& Karasu, 2019). Therefore, those studies reveal that the use of Edmodo as an instructional mode has improved student achievement and triggered the psychological conditions of the students which may encourage them to learn a lot.

Afew researches, however, were conducted to investigate Edmodo as a language assessment mode. Clarke (2015) and Oduntan, Ojuawo, \& Oduntan (2015) advocate that assessments need to be transformed into the digital domain as a paper-based test (PBT) seems to be problematic and the transformation of the assessment into the digital domain is likely to be successful for both teachers and students. Furthermore, PBT does not seem to have perfect security as well (McCabe, Trevino, \& Butterfield, 2001; Dick, Sheard, Bareiss, Carter, Joyce, Harding, \& Laxer, 2002) as students may cheat easily by peeking at their neighbor answers despite the presence of proctors (Franklyn-Stokes \& Newstead, 1995). By randomizing the order of questions or test items, especially multiple choice and short answer test items, such cheating will be harder to do by test takers and such randomization is extremely easy for computer-based test (CBT), but it is harder for PBT as more copies and prints of questions will be needed.

For this reason, Edmodo is likely to mediate digital-based assessments. Besides, the former researches on Edmodo were quantitative in nature and carried out widely at the university level (Qomariyah et al., 2019; Santikarn \& Wichadee, 2018; Ma'azi \& Janfeshan, 2018; Khodary, 2017). To strengthen the findings of previous researches, qualitative-based research needs to carry out to elucidate holistically about the particular social phenomena (behavior, perception, etc.). Therefore, this research was carried out to investigate how Edmodo was utilized to mediate digital class in English language teaching; how Edmodo facilitated students' engagement during the class; and how Edmodo mediated a teacher to assess students' learning outcomes.

\section{METHODS}

This study is qualitative in nature and aims to explore the effectiveness of Edmodo as a mode of instruction and assessment in the ELT classroom. The teacher carried out an assessment using Edmodo through the 'Quiz' feature and the students took the assessment together with their fellows in the school computer laboratory. The quiz was used to provide a CBT in the format of multiple-choice tests. Quiz could only be made by the teacher, while the students took merely the test. This feature was equipped with the time limit for taking the test, information about the quiz, the quiz title, and the quiz display. The process of scoring for each test item posted on the quiz was done automatically by the system of Edmodo. The participants were the twelfthgrade students of a secondary school located in Sragen territory, Indonesia which consisted of 286 students who were within the age of 16 to 18 . Among those students, 21 students were selected purposively (Creswell, 2003) to be interviewed regarding the application of Edmodo as a mode of instruction and assessment as well as its opportunity to mediate a more meaningful digital class. 
The data were subsequently collected by employing three different techniques, i.e. indepth interviews, mini-polling, and document analysis. The students were interviewed in a relaxed situation and it was carried out to explore information related to their learning motivation and the quality of their engagements and interactions during the instructional practices. Furthermore, the mini-polling was intended to find out students' perceptions of the use of Edmodo to mediate a digital class and to assess their learning. The mini-polling was uploaded through the Edmodo wall and the students responded by clicking the option that fits with their circumstances. Document analysis was finally conducted by examining the variety of documents, such as students' notes and comments posted on the Edmodo wall as well as teacher's reflections on his ways of instructions using Edmodo which were recorded through his reflective journal entries. Each method captured what was experienced by the teacher and students both individually or in groups, such as their thoughts, questions, and consequent of employing Edmodo as a mode of instruction and assessment. The data were subsequently validated through the triangulation technique (Sutopo, 2002). It was carried out to ensure that the data were mutually compatible and supportive of each other.

For this present study, the procedure of the digital-based instructional practices was carried out in several stages, i.e. (1) instructional activity began with the teacher firstly explains the course materials in the classroom; (2) after attending the instructional practices in the classroom, the students followed the digitalbased English instructions through Edmodo with the specified schedule; (3) the interactions between teacher and students were carried out in a separate place or location according to the agreed time proposed by the teacher and his students; (4) the teacher virtually guided the students to follow the instructional practices through digital class; and (5) finally, students carried out virtual discussions with their peers on the course materials provided by their teacher and the teacher provides any feedback virtually on various learning difficulties the students might encounter as well. At this stage, students and teachers could communicate with each other, even though they were in different locations.
The collected data were analyzed by following an interactive model of data analysis (Miles, Huberman, \& Saldana, 2014) with four fundamental stages, i.e. data collection, data condensation, data display, and drawing and verifying conclusion. The process of data collection was carried out as explained in the previous section and the use of multiple techniques was deliberately assigned to pursue the clarity of research data. Data condensation was the process of selecting, focusing, simplifying, abstracting, and/or transforming the data that appear in the full body of written-up field notes, interview transcripts, and documents. It was carried out by creating codes and categories to guide the data to research questions. Data was subsequently displayed in charts or tables. The data analysis was eventually ended by drawing and verifying the conclusions.

\section{FINDINGS AND DISCUSSION Findings}

As an instructional mode, Edmodo had the potential to play a paramount role in creating student-centered learning activities. Students' engagements could be observed and analyzed at any time as the engagements were wellrecorded on the Edmodo wall. The students having any learning difficulties might post them on the Edmodo wall so that their classmates could provide any comments and offer particular solutions. Additionally, teachers could immediately provide feedback on the students' learning difficulties. This section hereinafter presents various empirical findings of the use of Edmodo as an instructional mode as well as an assessment mode.

\section{Edmodo to Mediate a Digital Class in ELT}

When Edmodo was implemented as an English instructional mode, students' responses were identified tend to be varied and were different from one student to the other ones. It could be inferred from the results of minipolling that most of the students (about 68 percent) had a positive perception and agreed to the use of Edmodo as an instructional mode. The rest tended to hesitate and/or disagreed that English instructions need to be carried out by employing Edmodo. These students' positive perceptions denoted that Edmodo had a great opportunity for mediating digital classes in ELT. 
The students further argued that Edmodo-based instructions were no longer monotonous. The students mostly claimed that Edmodo was an effective and efficient mode for mediating digital classes. Students were challenged to engage intensively and digitally. As a complementary result, the digital class facilitated by Edmodo also encouraged students to learn English autonomously and independently. The independent and autonomous students have stimulated themselves to carry out any learning activities independently or with the help of others to achieve the particular competencies and it is really easy to achieve in a digital class by using Edmodo as a mode of learning.

By employing Edmodo to facilitate the digital class, the students were well-motivated to achieve their target of learning within a predetermined time. They strived hard to immediately complete their assignments as their learning activeness might always be monitored by their teacher and classmates, even by their parents online. Online monitoring on students' way of learning conducted by the teacher, classmates, and parents is an embodiment of digital class. This digital class has motivated students to learn a lot in achieving the predetermined learning objectives. Several indicators were showing the students' high motivation during the implementation of the digital class, such as the students had the high desires and courages to convey their interests, needs and learning problems to their teacher and fellows online; they participated actively during the process of preparation, implementation, and follow-up of their learning online; they were much more creative in completing any learning activities until the learning objectives were achieved; and they completed their assignment voluntarily without under pressure by the teacher. Students were also encouraged to seek references independently on various course materials to complete the assignments provided by their teacher. To sum up, it was known that Edmodo to mediate a digital class has already empirically proved and the instructional practices have significantly changed into the better ones as the students and teachers could interact with each other without time and place restrictions.

\section{Edmodo Facilitates Students' Engagement during the Class}

Edmodo facilitates teachers and students to carry out effective instructions. Several conveniences could be identified when English instructions utilized Edmodo as an instructional mode. Firstly, Edmodo enabled the students to improve the quality of communication with their teacher and classmates. In conventional practices of instruction, teacher-student and student-student communication sometimes run less effectively due to space and time restrictions. As a result, the teacher-student, student-student, and even student-teacher-parent communication were strongly tenuous so that a collaboration of learning was relatively harder to realize. It was quite different when Edmodo was applied as an instructional mode. The communication did not come about only inside the classroom, but also outside the classroom. The Communication barriers between students and teachers were no longer a fundamental problem as Edmodo was part of the instructional mode. Students-teacher communication ran well, even though they were not in the same locations. It means that students' engagement has already changed for the better when Edmodo-based instructional practices were applied in ELT classroom. Students could engage in actively during the class, both inside and outside the classroom, and interact effectively with the teacher and classmates digitally to achieve the specified learning objectives.

Secondly, Edmodo improved the students' collaborative attitudes. Through Edmodo, they might work together online to complete the assignment and to share any references or learning resources to complete the assignment. Good collaboration among a student and the others, a teacher with his students and a teacher with the students' parents exaggerated the conducive and enjoyable learning environment. This collaboration was relatively difficult to realize if they had to be in the same location. As an instructional mode, Edmodo facilitated virtual communication so that the collaboration could still be executed even though they were separated by distance and time. Therefore, Edmodo enabled learners to cooperate and collaborate in the virtual classroom environment. 
Empirically, the students collaborate easily with their classmates to complete the various assignments and projects provided by the teacher. The students believed that by employing Edmodo, the completion of their projects became easier as they could discuss them with their classmates online. As students' engagement and collaboration got better, they could subsequently develop the collegial attitude, critical voice and shared vision, which in turn not only helped them improve their academic output but also helped them enhance socio-emotional learning (Yadav, 2016) so that the target knowledge would be easily gained by the students (Bada, 2015). Through Edmodo, the collaboration ran in much more flexible ways to achieve the instructional objectives. This flexibility was certainly different from that of face-to-face instructional practices where the instructions took place only inside the classroom.

\section{Edmodo as a Mode of Assessment}

In general, many Indonesian English teachers have been applying the PBT to measure and assess student learning outcomes. With this mode of assessment, a teacher formerly prepared the test items; printed them on pieces of paper, and then distributed them to each student to take on. Students subsequently took the tests on a piece of paper and submitted them back to the teacher for review. Students took the tests in the classroom along with their classmates. Each student got the same format of test items, commonly multiple-choice tests, and those test items were sequentially ordered. This condition provided students a chance to cheat when they were taking and completing the tests. Students commonly preferred paper-based tests to digitally-based tests since they would have some opportunities to cheat easily and copy the answers provided by other classmates. As a result, the reliability and objectivity of tests would be a major problem.

Edmodo as an educational social network could be an alternative mode to assess student learning outcomes due to its user-friendly and practical aspects. One of the Edmodo features that could be used as an assessment mode is 'quiz'. This feature could be an assessment mode by using a variety of test formats, i.e. multiple-choice, true-false, short answer, essay, poll, etc. Besides, teachers could easily share a test to each student and set a deadline out for taking the test. As the deadline to take the test could be previously set out, students could no longer take the test beyond the available time. If the test was taken beyond the available time, it would be automatically rejected by the Edmodo system. Unlike paper-based tests, the sequences of test items on Edmodo could be randomized automatically by the Edmodo system so that each student enabled to possess a set of test items with the different orders. The students had to take the test directly on the computer screen and the answers given by the students could no longer be seen when those students switched to take the next questions. As a result, it reduced the students' opportunities to cheat their classmates' answers.

It seemed that cheating was not facilitated when Edmodo was utilized as a mode of assessment. In other words, students got some difficulties to cheat when they took the test by using Edmodo as they could not steal a glance at the answers of their classmates. It was quite different when a PBT was employed to assess students' learning. It was likely that cheatings were relatively easy to do as students might peek at their neighbor answers. If cheating was not facilitated, the reliability, objectivity, fairness, and objectivity of the test could be achieved effectively.

Edmodo was one of the alternative modes a teacher might utilize for assessment. However, some low-achieving students preferred to use the PBT as they had the opportunity to peek at easily their neighbor answers. Therefore, the CBT through Edmodo, or other platforms, became a pivotal leap in language assessment. With Edmodo, objectivity, fairness, accuracy, validity, and reliability of the test could be achieved better and cheating was not facilitated. It was reasonable that some low-achieving students are uncomfortable if the test was administered through Edmodo. The students understood that the Edmodo-based test results were more objective and illustrated their authentic abilities as they were. Although some low-achieving students preferred the PBT to that of CBT, some other students thought that the $\mathrm{CBT}$ could reduce their anxiety while they were taking the test. They were more relaxed while taking the CBT. In contrast to the PBT, students stated that they frequently got nervous and lack of concentration. 
One reason was that when they took a set of the PBT, they tended to be nervous as they were worried that they could not finish the test due to the time restrictions. It indicated that Edmodobased tests (the CBT) could reduce students' anxiety while they were taking the test. If students' anxiety could be reduced, students' test performance could be increased significantly.

\section{Discussions}

The present study emphasizes more on exploring three different roles of Edmodo as an instructional mode, i.e. Edmodo as a medium of digital class in English language teaching; Edmodo as a facility for students' engagement; and Edmodo as a medium of assessment. In general, Edmodo as an instructional mode can be used by teachers and students to share links, notes, or documents. Teachers may also provide students a lesson record, assessment, and assignments. Edmodo can be particularly used to organize instructional activities which are much more fun for students; to create a close relationship between students and teachers without space and time restrictions; to facilitate better communication between teacher, students, and parents constructively; to carry out an instructional activity anytime and anywhere; and to provide teachers a medium to carry out computer-based assessments so that the accuracy and reliability of the test are easier to achieve.

\section{Edmodo to Mediate a Digital Class in ELT}

In general, students have a positive perception of utilizing Edmodo as an English language instructional mode. They believe that the use of Edmodo has been able to facilitate a lively instructional activity so that instructional objectives are easier to achieve. Following this positive perception, students are well-motivated to find out the proper solutions to cope with their learning difficulties by asking their peers and teachers digitally or online. It means that Edmodo allows the students to carry out an online collaboration with their peers and teachers for better learning. The students are well-encouraged by themselves to collaborate and overcome the learning difficulties independently without the presence of the teacher. Furthermore, Santikarn \& Wichcadee (2018) report that incorporation of Edmodo into instructional practices allows students to be autonomous learners. In addition,
Thibaut (2015) and Khodary, (2017) prove that the utilization of Edmodo in language instructions encouraged the students to engage in self-directed learning and peer-teaching practices.

This positive perception enables each student to achieve the predetermined instructional objectives much more easily as well. Kosar (2016) notes that students' positive perceptions embark to promote students' learning strategies and finally students will successfully achieve the desired instructional objectives. The students can arrange and plan their strategy of learning to make sure that they could enhance their knowledge by collaborating with their friends online. It is in line with Al-Zumor et al. (2013) and Liu \& Yu (2012) who reveal that students' positive perception has enhanced students' collaboration and demonstrated better learning efficacy, higher motivation for learning, and students' performance is predictable as well. Therefore, students' positive perceptions of Edmodo as a digital platform of learning have been proven to bring about much more effective and efficient instructional activities.

Edmodo as an information technologybased instructional mode is applicable to cope with the limitations of conventional, face-toface instructions. It is relatively difficult to bring the students into dynamic learning activities when face-to-face instruction is taking place as the engagements and interactions are restricted solely in the classrooms. As an instructional mode, many students are of the view that when an English instruction takes advantage of Edmodo, the instructions come in much more interesting, compelling, and effective. Therefore, Chan (2002) states that information technologybased instructions could improve the efficiency, effectiveness, and productivity of instructions. It is because the instructional practices do not take place only inside the classroom, but also outside the classrooms; students and teachers can virtually interact and carry out a discussion with each other outside the classroom (Ali, 2015; Mokhtar, 2016).

The technology-based instructions that enable the students and teachers to carry out virtual communication and interaction outside the classroom are as the digital class. As a digital class is employed, the practices of English instructions will be flexible and dynamic as it 
is carried out virtually without space and time restrictions. Therefore, Rauschenberg (2016) reports that a digital class that is facilitated by technology provides students and teachers some elements of control over time, place, path, and/or pace. Students are able to share various questions related to learning difficulties with their classmates and teacher at any time as well. Their classmates subsequently provide any responses virtually and the teacher can immediately provide any virtual feedback as well. They may discuss each other without having to be in the same places or locations. Therefore, ShamsAbadi, Ahmadi, \& Mehdrad (2015) point out further that one of the impacts of employing Edmodo as an instructional mode is that Edmodo provides students an opportunity to submit the assignments without the need for face-to-face interactions. Additionally, Edmodo as one of the technology-based instructional modes has been able to shift the conventional face-to-face class into digital class because a teacher and students can virtually interact with each other online without time and place restrictions.

\section{Edmodo Facilitates Students' Engagement during the Class}

Students' engagement during the class is likely to encourage them for having collaborative and constructivist-learning environment. Edmodo as a social and educational network realizes this kind of learning environment effectively. It refers to a learning environment that emphasizes more on the process and freedom of exploring knowledge and efforts to construct experiences. In other words, the environment provides students large opportunities to learn and find out their own competencies, knowledge and experiences needed to develop by themselves. It also provides students the opportunities to express their ideas in their own language; to think about their experiences so that students become much more creative and imaginative; and to bring about a conducive learning interaction and collaboration. During this learning environment, students have actively engaged during the whole process of learning. Edmodo, as a digital mode of learning, is able to effectively facilitate the digital class in such a way that the students' engagement run in two ways, online and offline. In addition, Rock \& Wilson, (2005) point out that the digital class that is developed through the implementation of Edmodo is to support constructivism-based instructions, i.e. the instructions which emphasize more on social and collaborative activities and students subsequently construct their knowledge from various learning sources as a result of social interactions with their classmates as well as their teacher.

An environment of multidirectional interactions between teachers, students, and students' parents in cyber space allows the students to get into a cycle of constructing their truths and testing against the other's truths. Therefore, Ulloa (2013) states that the nature of constructivism is the idea that students need to discover and transform any complex information into different situations. On this basis, Edmodobased instructions are supposed to be packaged into a practice of constructing knowledge, not merely receiving knowledge. Additionally, Mokhtar and Dzakaria (2015) advocate that Edmodo is currently the best instructional mode to develop digital-based social network classes. Also, Edmodo can empirically allow students into autonomous learners, as it is also supported by Santikarn \& Wichadee (2018), in the context of a digital class. Since the students may set out their own learning targets independently and try to determine the steps needed to achieve the learning targets.

Edmodo encourages students to be actively engaged in English instructions online. It is a portal that provides many facilities for learning English so that students are well-motivated to be actively engaged in instructional practices. Furthermore, Riasati et al. (2012) elucidate explicitly that integration of technology in instructional practices is a concept of digital class and it is recommended for a wide array of reasons, i.e. engagement, improvement in academic ability, paradigm shift, assessment shift, and collaborative learning enhancement. Through Edmodo, students collaborate with their classmates virtually, either in pairs or in small groups. The collaboration is an effective method of learning English as it can activate the participation of the students during the class and improve their language proficiency (Maming, 2019). The students' engagements and collaborations do not come about intensively and extensively in conventional classrooms due to time constraints. Thus, Edmodo has changed the 
students' ways of learning that formerly tend to be isolative and subsequently transformed into an online collaborative way of learning.

\section{Edmodo as a Mode of Assessment}

PBT is a test format that is held in written forms and uses paper. All questions are presented on pieces of paper and the students answer the questions on pieces of paper as well. In contrast, CBT is a test that is held with the assistance of the computer. Different from that of CBT, PBT is relatively easier to prepare and develop. The teacher may construct it quickly in a very short time. However, some shortcomings may be unavoidable when the PBT is applied in the classroom. The main shortcoming is that there would be large opportunities for the students to commit fraud, and as stated by Clarke (2015), it is problematic in language assessment. Therefore, the transformation of the assessment into the digital domain or CBT is likely to be fruitful for both teachers and students. As it is advocated by Oduntan et al. (2015) that the performance of students when they write computer-based tests is better than the performance of the same students who write paper-based tests. In the context of assessment In Indonesia, cheating is still a big problem the teacher should minimize and CBT could take a pivotal role to minimize cheating the students may do during taking the test.

The CBTs through Edmodo are different from those of the PBTs. Edmodo can be an alternative mode of assessment so that the results of the test can also be more objective and reliable. Through Edmodo as an assessment mode, cheating is not facilitated and no opportunities for students to copy their classmates' answers. In other words, students take the tests by themselves. If objectivity and reliability of a test are two important aspects that need to accomplish, Edmodo facilitates achieving these aims effectively. Therefore, Ekmekci (2016) claims that Edmodo can be an effective assessment technique as well as an instructional mode through which teachers are able to share course materials, notes, links, and documents. He points out further that teachers may prepare quizzes and a set of tests with different question types which language teachers are easy to generate.

Although some low-achieving students prefer the PBT to that of CBT, the CBT does not facilitate students to peek at their neighbor answers. Edmodo is an innovative mode of assessment in language teaching. Edmodo-based assessments reduce students' anxiety when they are taking the tests as well. It is an important finding as the students' anxiety may harm students' academic achievement, self-efficacy, and self-concept (Dobson, 2012); anxiety during the tests has also become a prominent problem in school (Trifoni \& Shahini, 2011); and anxiety effects on students' attitudes towards the tests and motivation to take tests (Dodeen, 2014). To sum up, Edmodo reduces students' anxiety when they are taking tests and reduce students' opportunities for cheating as well.

\section{CONCLUSION}

In light of the research findings, it can be concluded that Edmodo as a mode of instruction is likely to mediate digital classes as any parties can interact virtually without having any significant obstacles. Due to the use of Edmodo, multidirectional interactions between teachers, students, and students' parents take place without time and place restrictions. The students' engagements improve better when digital class is implemented to teach them English. Students who formerly tend to be isolative during the faceto-face classroom, they subsequently transform into active and dynamic learners. Additionally, Edmodo facilitates teachers to carry out a computer-based test sot that the assessments will be objective, accurate, fair, valid, and reliable. It presents an innovative assessment as cheating is not facilitated and students' anxiety can be minimized as well.

There are some implications for the results of the study. Firstly, teachers may need to reflectively review on their ways of teaching to improve the quality of instructional practices. They need to transform conventional, face-to-face classrooms into digital classes, or they need to combine both into a blended class. Secondly, if teachers rightly assume that objectivity and reliability are two important aspects in assessment, and if they further think of innovation in assessment, it is justifiable to replace the paper-based tests with the alternative modes like that of Edmodo-based assessment. However, this research emphasizes more on the efforts of revealing the effectiveness of Edmodo to facilitate the development of digital classes 
and as a medium of assessment in English class. It needs to be explored deeply if the students' preference and attitudes towards Edmodo as an instructional medium is a truly determinant of students' learning achievement.

\section{REFERENCES}

Ali, Z. (2015). A case study of tertiary students' experiences using Edmodo in language learning. International Journal of Language Education and Applied Linguistics, 02(2015), 39-48. doi:10.15282/ijleal.v2.462.

Al-Said, K. M. (2015). Students' perceptions of Edmodo and mobile learning and their real barriers towards them. TOJET: The Turkish Online Journal of Educational Technology, 14(2), 167-180. http://www. tojet.net/articles/v14i3/14313.pdf.

Al-Zumor, A. W. Q., Al-Refaai, I. K., Eddin, E. A. B., \& Al-Rahman, F. H. A. (2013). EFL Students' perceptions of a blended learning environment: Advantages, limitations, and suggestions for improvement. English Language Teaching, 6(10), 95-110. doi:10.5539/elt.v6n10p95.

Arkorful, V., \& Abaidoo, N. (2014). The role of e-learning, the advantages, and disadvantages of its adoption in higher education. International Journal of Education and Research, 2(12), 397-410. doi:10.4236/jcc.2014.22007.

Bada, S. O. (2015). Constructivism learning theory: A paradigm for teaching and learning. IOSR Journal of Research \& Method in Education, 5(6), 66-70. doi:1 0.1080/1743727X.2014.908338.

Bakar, A. Y. A. (2016). "Digital Classroom": An innovative teaching and learning technique for gifted learners using ICT. Creative Education, 7(1), 55-61. doi:10.4236/ce.2016.71006.

Cakrawati, L. M. (2017). Students' perceptions of the use of online learning Modes in ELT classrooms. English Language Teaching and Technology Journal, 1(1), 22-30. doi:10.17509/elt\%20tech.v1i1.9428.
Çelik, S., \& Aytın, K. (2014). Teachers' views on digital educational modes in English language learning: Benefits and challenges in the Turkish context. The Electronic Journal for English as Second Language, 18(2), 1-18. doi:10.18178/ ij111.2017.3.2.108.

Chan, F. M. (2002). ICT in Malaysian schools: Policy and strategies. http://www. share4dev.info/kb/documents/3513.pdf.

Clarke, R. J. (2015). Transforming assessments into the digital domain. In Y. Zhang (Eds). Handbook of mobile teaching and learning. Berlin: Springer, pp. 1-22.

Creswell, J. W. (2003). Research design qualitative, quantitative, and mixed methods approach. California, CA: Sage Publication, Inc.

Daiute, C. (2013). Educational uses of the digital world for human development. LEARNing Landscapes, 6(2), 341-360. doi:10.36510/ learnland.v6i2.605.

Dick, M., Sheard, J., Bareiss, C., Carter, J., Joyce, D., Harding, T., \& Laxer, C. (2002). Addressing student cheating: Definitions and solutions. Innovation and Technology in Computer Science Education, 6(2), 172-184. doi:10.1145/960568.783000.

Dobson, C. (2012). Effect of academic anxiety on performance students with and without learning disabilities and how students can cope with anxiety at school (Unpublished Master Tesis, Northern Michigan University). https://www.nmu. edu/education/sites/DrupalEducation/ files/UserFiles/Dobson_Cassie_MP.pdf.

Dodeen, H. M. (2014). Test-taking skills of secondary students: the relationship with motivation, attitudes, anxiety, and attitudes towards tests. South African Journal of Education, 34(2), 1-18. doi:10.15700/201412071153.

Ekmekci, E. (2016). Integrating Edmodo into foreign language classes as an assessment mode. Participatory Educational Research, (Special Issue 2016-I), 1-11. 
doi:10.17275/per.16.spi.1.1.

Franklyn-Stokes, A, \& Newstead, S. E., (1995) Undergraduate cheating: Who does what and why? Studies in Higher Education, 20(2), 159-172. doi:10.1080/0307507951 2331381673 .

Garrett, R. K., \& Danziger, J. N. (2008). Disaffection or expected outcomes: Understanding personal Internet use during work. Journal of ComputerMediated Communication, 13(4), 937-958. doi:10.1111/j.1083-6101.2008.00425.x.

Ghavifekr, S., \& Rosdy, W. A. W. (2015). Teaching and learning with technology: Effectiveness of ICT integration in schools. International Journal of Research in Education and Science, 1(2), 175-191. doi:10.21890/ijres.23596.

Khodary, M. M. (2017). Edmodo use to develop Saudi ELT students' self-directed learning. English Language Teaching, 10(2), 123135. doi:10.5539/elt.v10n2p123.

Kosar, G. (2016, 14-17 April). A study of EFL instructors' perceptions of blended learning. Paper presented at International Conference on Teaching and Learning English as an Additional Language (GlobELT), Turkey. https://www. sciencedirect.com/science/article/pii/ S1877042816313337.

Kuzu, A. (2008). Views of pre-service teachers on blog use for instruction and social interaction. Turkish Online Journal of Distance Education, 8(3), 34-51. doi:10.4304/jltr.4.5.975-985.

Kwok, W. \& Kong, S. C. (2016). Exploration of pedagogical use of social learning mode and word processing productivity tool in peer-assessment and self-editing tasks in elementary English writing classrooms. Journal of Educational Computing Research, 53(2), 284-309. doi:10.1177/0735633115597490.

Li, Y. W. (2016). Transforming conventional teaching classroom to learner-centered teaching classroom using multimedia:
Mediated learning module. International Journal of Information and Education Technology, 6(2), 105-112. doi:10.7763/ IJIET.2016.V6.667.

Liu, W. \& Yu, H. (2012). Effectiveness study of English learning in a blended learning environment. Theory and Practice in Language Studies, 2(3), 524-530. doi:10.4304/tpls.2.3.524-530.

Lubis, A. H. (2018). ICT integration in 21stcentury Indonesian English language teaching: Myths and realities. Cakrawala Pendidikan, 37(1), 11-21. doi:10.21831/ cp.v37i1.16738.

Ma'azi, H. \& Janfeshan, K. (2018). The effect of Edmodo social learning network on Iranian ELT learners writing skills. Cogent Education, 5(1), 1-17. doi:10.1080/23311 86X.2018.1536312.

Maming, K. (2019). Activating EFL learners by integrating team-based learning with collaborative strategic reading. Litera, 18(2), 297-311. doi:10.21831/1tr. v18i2.23815.

McCabe, D. L, Trevino, L. K., \& Butterfield, K. D. (2001). Cheating in academic institutions: A decade of research. Ethics \& Behaviour, 11(3), 219-232. doi:10.1207/ S15327019EB1103_2.

Miles, M., Huberman, A. M., \& Saldana, J. (2014). Qualitative data analysis: A methods sourcebook ( $3^{\text {rd }}$ Ed.). Los Angeles: Sage Publications.

Mokhtar, F. A. (2016). Rethinking conventional teaching in language learning and proposing Edmodo as intervention: A qualitative analysis. Malaysian Journal of Educational Technology, 4(2), 22-37. https://www.mojet.net/article/rethinkingconventional-teaching-in-languagelearning-and-proposing-edmodo-asintervention.

Mokhtar, F. A, \& Dzakiria, H. (2015). Illuminating the potential of edmodo as an interactive virtual learning mode for English language learning and teaching. 
Malaysian Journal of Distance Education, 17(1), 83-98. http://mjde.usm.my/ vol17_ 1 2015/MJDE\%2017(1)\%20 2015\%20-\%20Art.\%206(83-98).pdf.

Oduntan, O. E., Ojuawo O. O., \& Oduntan E. A., (2015). A comparative analysis of student performance in Paper Pencil Test (PPT) and Computer Based Test (CBT) examination system. Research Journal of Education Studies Review, 1(1), 24-29. http://pearlresearchjournals.org/journals/ rjesr/archive/2015/A pril/Abstract/ Oduntan\%20et\%20al.html.

Pardede, P. (2019). Pre-service ELT teachers' perception of blended learning. Journal of English Teaching, 5(1), 1-14. doi:10.33541/jet.v5i1.955.

Polat, E., Cagiltay, K., \& Karasu, N. (2019). Tangible objects and mobile technology: Interactive learning environments for students with learning disabilities. In Y. Zhang \& D. Cristol (Eds.). Handbook of mobile teaching and learning. Berlin, Heidelberg: Springer, pp. 2-21.

Purnawarman, P., Susilawati, S., \& Sundayana, W. (2016). The use of Edmodo in teaching writing in a blended learning setting. Indonesian Journal of Applied Linguistics, 5(2), 242-252. doi:10.17509/ ijal.v5i2.1348.

Qomariyah, S., Gunarhadi, G., \& Rejekiningsih, T. (2019). Edmodo in blended learning to increase language learners' understanding of learning grammar for TOELT. International Journal of Educational Research Review, 4(1), 8287. doi:10.24331/ijere.486653.

Rauschenberg, S. (2016). Connection for classrooms grant program annual report. https://gosa.georgia. gov/document/publication/2016connections-classrooms-annual-reportdecember-2016/download.

Relan, A., \& Gillani, B. J. (1997). Web-based instruction and the traditional classroom: similarities and differences. In B. Khan (Ed.). Web-based instruction. New Jersey,
NJ: Educational Technology Publications, pp. 25-37.

Riasati, M. J., Allahyar, N., \& Tan, K. (2012). Technology in language education: Benefits and barriers. Journal of Education and Practice, 3(5), 25-30. doi:10.1016/j. sbspro.2012.11.051.

Rock, T. C. \& Wilson, C. (2005). Improving teaching through lesson study. Teacher Education Quarterly, 3(2), 77-92. doi:10.1108/20468251211224163.

Santikarn, B. \& Wichadee, S. (2018). Flipping the classroom for English language learners: A study of learning performance and perceptions. International Journal of Emerging Technologies in Learning (IJET), 13(9), 123-135. doi:10.3991/ijet. v13i09.7792.

Shams-Abadi, B. B., Ahmadi, S. D., \& Mehrdad, A. G. (2015). The effects of Edmodo on ELT learners' writing performance. International Journal of Educational Investigations, 2(2), 88-97. doi:10.20961/ ijpte.v1i2.5038.

Sutopo, H. B. (2002). Metodologi penelitian kualitatif: Dasar teori dan penerapannya dalam penelitian. [Qualitative research methodology: Basic theory and its application in research]. Surakarta: Universitas Sebelas Maret Press.

Thibaut, P. (2015). Social network sites with learning purposes: exploring new spaces for literacy and learning in the primary classroom. Australian Journal of Language and Literacy, 38(2), 8394. https://www.alea.edu.au/documents/ item/1174.

Trifoni, A., \& Shahini, M. (2011). How does exam anxiety affect the performance of university students? Mediterranean Journal of Social Sciences, 2(2), 93-100.

Tsiakyroudi, M. (2018). Exploring the effectiveness of Edmodo on Greek ELT B1 learners' motivation to write. Research Papers in Language Teaching and Learning, 9(1), 96-112. https://rpltl.eap. 
gr/images/2018/RPLTL 9 full.pdf.

Ulloa, T. F. (2013, 22-23 February). Teaching with social networks: Facebook, Twitter, and Edmodo. Paper presented at The $16^{\text {th }}$ Annual CSU Teaching Symposium, The California Maritime Academy, Vallejo CA. https://www. csum.edu/c/document_library/get file?uuid $=\quad 281671 \mathrm{e} 5-79 \mathrm{fa}-419 \mathrm{~b}-8420-$ $8 \mathrm{f} 4 \mathrm{e} 12344 \mathrm{~d} 4 \mathrm{~b} \&$ groupId $=72269$.

Yadav, R. (2016). Role of constructivism in learning. International Journal of Educational Studies, 3(3), 93-97. https:// journals.esciencepress.net/index.php/ IJES/article/view/1591.

Zakana, M. E.\& Fomsi, E. F. (2019). Effect of social networking sites on students' engagement and motivation in computer science in Bayelsa State, Nigeria. European Scientific Journal, 15(5), 18577431. doi:10.19044/esj.2019.v15n5p132.

Zuhdi, D., \& Nurhadi. (2019). Culture based teaching and learning for Indonesian as a foreign language in Yogyakarta. Cakrawala Pendidikan, 38(3), 465-476. doi:10.21831/cp.v38i3.26297. 